\title{
THE
}
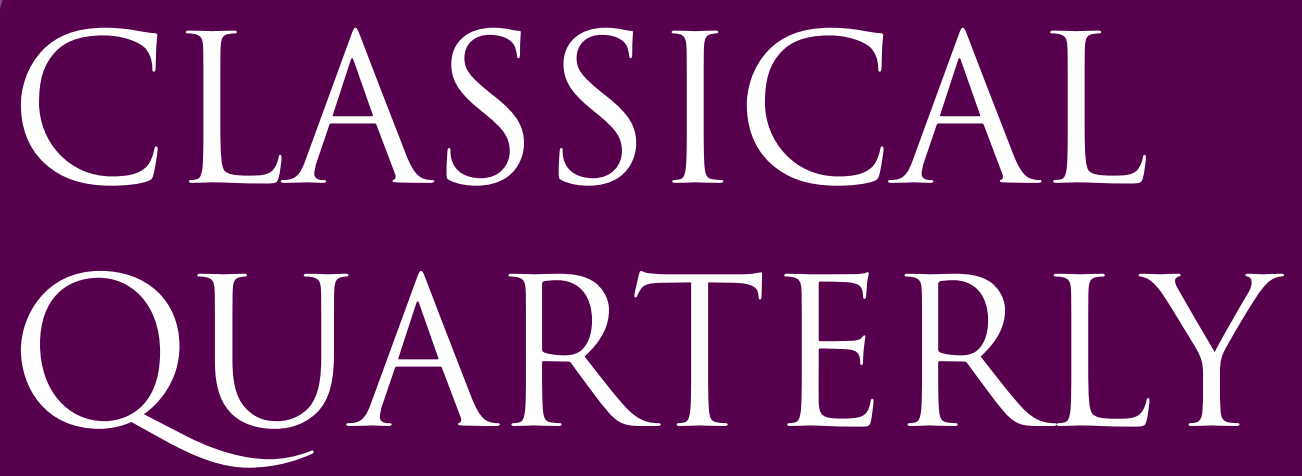

\section{NEW SERIES}

\section{VOLUME 63 • NUMBER $1 ・ 2013$}

PUBLISHED FOR THE CLASSICAL ASSOCIATION BY CAMBRIDGE UNIVERSITY PRESS 


\section{CLASSICAL QUARTERLY}

PUBLISHED IN APRIL AND OCTOBER IN EACH YEAR

CLASSICAL ASSOCIATION JOURNALS BOARD

Professor C. Carey (Chairman)

Miss C. Davenport (Secretary)

Dr R. Armstrong

Dr M. Bradley

Dr R. Brock

Mr P. Hooker

Dr Z. Newby

Professor S.P. Oakley

Professor T. Parkin

Professor J.H.D. Scourfield

Dr E.J. Stafford
Ex officio

Dr V. Izzet (Editor, Greece \& Rome)

Dr R. Shorrock (Editor, Greece \& Rome)

Dr J. Taylor (Editor, Greece \& Rome)

Professor B.J. Gibson (Editor, Classical Quarterly)

Dr A. Morrison (Editor, Classical Quarterly)

Dr R. Rees (Editor, Classical Review)

Professor M. Edwards (Editor, Classical Review)

\section{EDITORS}

Bruce Gibson, University of Liverpool, UK

Andrew Morrison, Manchester University, UK

\section{ADMINISTRATOR}

Clare Roberts

The Classical Quarterly is published by Cambridge University Press on behalf of the Classical Association. It is under the control of a Journals Board consisting of a Chair appointed by the Council of the Classical Association, the Chair of the Council, the Secretary to the Council, the Treasurer, and six further members appointed by Council.

\section{SUBSCRIPTIONS}

The Classical Quarterly (ISSN 0009-8388) is published twice a year in May and December. Two parts form a volume. The subscription price which includes delivery by air where appropriate (but excluding VAT) of volume 63,2013 , which includes print and online access, is $£ 151.00$ (US $\$ 273.00$ in USA, Canada and Mexico) for institutions. The online-only price available to institutions is $£ 138.00$ (US \$251.00). Members of the Classical Association may subscribe at reduced rates. Single parts are $£ 76.00$ (US $\$ 138.00$ in USA, Canada and Mexico) plus postage. EU subscribers (outside the UK) who are not registered for VAT should add VAT at their country's rate. VAT registered members should provide their VAT registration number. Japanese prices for institutions (including ASP delivery) are available from Kinokuniya Company Ltd, P.O. Box 55, Chitose, Tokyo 156, Japan.

Orders, which must be accompanied by payment, may be sent to your subscription agent or direct to the publisher: Cambridge University Press, The Edinburgh Building, Shaftesbury Road, Cambridge CB2 8RU; or in the USA, Canada and Mexico: Cambridge University Press, Journals Fulfillment Department, 100 Brook Hill Drive, West Nyack,New York 10994-2133, USA. Periodicals postage paid at New York,NY and at additional mailing offices.

\section{COPYING}

This journal is registered with the Copyright Clearance Center, 222 Rosewood Drive, Danvers, MA 01923, USA. Organisations in the USA who are also registered with the C.C.C. may therefore copy material (beyond the limits permitted by sections 107 and 108 of U.S. Copyright law) subject to payment to the C.C.C. of the per copy fee of $\$ 30.00$. This consent does not extend to multiple copying for promotional or commercial purposes. Code 0009-8388/12. ISI Tear Sheet Service, 3501 Market Street, Philadelphia, PA 19104, USA, is authorised to supply single copies of separate articles for private use only. Organisations authorised by the Copyright Licensing Agency may also copy material, subject to the usual conditions. For all other use, permission should be sought from Cambridge or from the American Branch of Cambridge University Press.

The Classical Quarterly is included in the Cambridge Journals Online journals service, which can be found at http://journals.cambridge.org/jid_CAQ. Tables of contents are freely available. The full text is available online from your desktop if your library has a subscription, or if you subscribe as a member of the Classical Association. For further information on other Press journals access http://cambridge.org/journals.

(C) The Classical Association 2013

ISSN 0009-8388

Printed in the United Kingdom by Bell and Bain, Glasgow, UK 


\section{CLASSICAL QUARTERLY}

NEW SERIES MAY 2013 VOL. 63, NO. 1

\section{CONTENTS}

Iliad 24 and the Judgement of Paris

Truth and genre in Pindar

C.F. Mackie 1

Arum Park

17

Epinician variations: music and text in Pindar, Pythians 2 and 12

Tom Phillips

Pindar and Euripides on sex with Apollo

Emily Kearns

Madness and bestialization in Euripides' Heracles Antonietta Provenza

How to address the Athenian assembly: rhetoric and political tactics in the debate about Mytilene (Thuc. 3.37-50)

Pleasure and truth in Republic 9 Edward M. Harris $\quad 94$ David Wolfsdorf 110

Nomothesia in Classical Athens: what sources should we believe?

Mirko Canevaro

De generatione et corruptione 2.3: does Aristotle identify the contraries as elements?

Timothy F. Crowley

The text of the Aristotelian Mechanics

Which 'Athenodorus' commented on Aristotle's

foyce van Leeuwen

Categories?

Michael F. Griffin

Egyptian warriors: the machimoi of Herodotus and the Ptolemaic army

Christelle Fischer-Bovet

Eunus: the cowardly king

Peter Morton

Some fragments of Republican drama from Nonius

Marcellus' Sources 26, 27 and 28

Notes on the text of Cicero's Philippics

The descendants of Petrarch's Pro Archia

The woman's part: the speaking beloved in Roman elegy

Farrett T. Welsh

S.P. Oakley

feroen De Keyser

Two conjectures in Horace: Odes 1.16 .8 and 1.35.25

Megan O. Drinkwater

Horace, Carmen 4.2.53-60: another look at the uitulus

David Kovacs

Facqueline Klooster

The emergence of a novel onomastic pattern: cognomen + nomen in Seneca the Elder

Frontinus' cameo role in Tacitus' Agricola

Arturo Echavarren

Alice König

Still waters run deep: Plutarch, Aemilius Paulus 14

W. Feffrey Tatum

Performing paideia: Greek culture as an instrument for social promotion in the fourth century A.D.

Two allusions to Terence, Eunuchus 579 in Jerome

$\begin{array}{rr}\text { Lieve Van Hoof } & 387 \\ \text { Andrew Cain } & 407\end{array}$




\section{Shorter Notes}

Who sings the hoopoe's song? Aristophanes,

$$
\text { Birds 202-8 }
$$

Aristophanes, Wealth 227-9

Dramatic aspects of Plato's Protagoras

Marcia Catonis and the fulmen clarum

Cicero's silva (a note on Ad Atticum 12.15)

A syntactical Hellenism at Horace, Satires 1.3.120-1, and a possible imitation in Livy

Virgil's lime-wood yoke (Georgics 1.173-4)

Propertius 3.10.17

Women scorned: a new stichometric allusion in the

$$
\text { Aeneid }
$$

Vayos F. Liapis

413

David F. Facobson

417

M.F. Burnyeat 419

Patrick Tansey 423

Brian Walters 426

Macrobius, Saturnalia 5.11.1-3 and a Virgilian reading

Ovid, Remedia amoris 95: uerba dat omnis amor

Solving problems with acrostics: Manilius dates Germanicus

Tacitus, Annals 1.1.1 and Aristotle

Three notes on the Euclides Latinus preserved in the Verona manuscript, Biblioteca Capitolare XL (38)

Benjamin Victor $\quad 430$

Francis Cairns $\quad 434$

Marc Dominicy 439

Dunstan Lowe $\quad 442$

Salvatore Monda 445

L.B.T. Houghton 447

Robert Colborn $\quad 450$

Matthew Leigh 452

Erik Bohlin 455 